\title{
Input, Output, And Negotiation Of Meaning In Spanish Conversation Classes
}

Graziela Rondon-Pari, SUNY Brockport, USA

\begin{abstract}
This research study is based on the analysis of speech in three Spanish conversation classes. Research questions are: What is the ratio of English and Spanish spoken in class? Is classroom speech more predominant in students or the instructor? And, are teachers' beliefs in regards to the use of English and Spanish consistent with their classroom practices? Data were obtained from the tape-recording of fifteen intermediate Spanish college level lessons. Data also came from non-participant observations and an interview with each of the three instructors. It was found that while the use of the primary language versus target language varied greatly among the different instructors, there was a large amount of teacher over student speech in two of the three instructors' classes. Results also indicate that there is consistency between beliefs regarding the use of English and Spanish in two of the instructors, but not in the third instructor.
\end{abstract}

Keywords: Input; Instructors' Beliefs; Negotiation of Meaning; Output; Spanish

\section{INTRODUCTION}

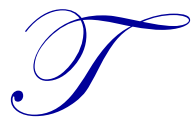

his article explores input and output taking place in three college level Spanish classrooms, represented by measurement and analysis of the amount of the primary language (L1) and the target language (L2) used by three instructors. It also explores whether instructors are aware of their beliefs regarding the use of L1 and L2 in the classroom. Input, output and negotiation of meaning are necessary components in the foreign language acquisition process, especially because there is not much opportunity for learners to be exposed to the L2 outside the classroom.

\section{THEORETICAL BACKGROUND}

\subsection{Input}

"Input refers to the linguistic forms to which learners are exposed" (Mackey \& Abbuhl, 2005). The input in the foreign language classroom comes especially from the instructor, in the form of oral input, but there could also be input generated by the students in the listening and speaking process. This study takes into consideration oral input coming from both learners as well as instructors.

In the field of foreign and second language acquisition there is a prevalent assumption that the continuous use of the L2 is necessary (Chaudron, 1988; Day, 1985; Ellis, 1984; Krashen, 1985). Therefore, speaking in the target language as much as possible is necessary for the acquisition of the L2. Regarding this issue Day (1985) stated:

It is widely assumed that the use of the target language is one of the crucial variables in the successful acquisition of the target language-the more often students use or practice the second or foreign language, the more likely they are to learn it. (p. 257)

At the same time, not all types of input benefit the learning process. Input should be meaningful and comprehensible (Krashen, 1985). Regarding the meaningfulness of input, Selinker (1972) stated that psychologically relevant data in the acquisition process as well as relevant behavioral events lead to meaningful performance and are relevant to L2 
learning. At a time when behavioral psychology represented by Skinner was in vogue, learning was viewed as "the result of repeated responses to stimuli that led to habit formation... In the L2 classroom, this approach to learning translated into the audiolingual method, with its stress on overt correction and imitation through drills." (Sanz 2005, p. 8). Selinker further argued that because L2 input should be meaningful, the "performance of drills in a secondlanguage classroom is, by definition, not meaningful performance" (p. 210) and therefore it is of minor interest. Fortunately, the field of foreign and second language acquisition witnessed a reaction to the audiolingual method with its emphasis on drills in favor of "communicative competence", a phrase coined by Savignon (1972). Communicative competence is " ... the ability of language learners to interact with other speakers, to make meaning, as distinct from their ability to perform on discrete-point tests of grammatical knowledge" (Savignon 1991, p. 264).

Later on influential work on input carried on by Long (1996) pointed to the importance of interaction and when impasses in interaction took place, to negotiation of meaning.

\subsection{Negotiation of Meaning}

Negotiation of meaning connects input and output, linked by interaction, three important elements in the acquisition of L2 (Long 1996). Negotiation of meaning "refers to the efforts learners and their interlocutors make to modify or restructure interaction in order to avoid or overcome difficulties in input comprehensibility" (Mackey \& Abbuhl 2005, p. 207). The benefit from using negotiation of meaning as a tool extend to the fact that by using this strategy, the use of L1 is minimized, as negotiation is practiced instead of translation of the unfamiliar form or vocabulary. As a matter of fact, Pica (1996) stated that "negotiation plays an important role in L2 learning, not by meeting learner's needs directly, but rather as facilitating these two important processes of comprehension and production" (p. 2). Pica (1987) further explained that negotiated input becomes more comprehensible than nonnegotiated input. Another reason for the importance of negotiation of meaning relies in the fact that it encourages L2 output. "Negotiation can promote acquisition because it allows learners to understand words and structures beyond their present level of competence and, eventually, to incorporate them into their L2 production" (De la Fuente 2002, p. 83). Output is a necessary component in the interaction process, as we will see in the next section.

\subsection{Output}

Swain's $(1985,1995)$ output hypothesis supports the idea that comprehensible input is not enough to promote language learning, but that comprehensible output is also necessary.

Comprehensible output implies "the delivery of a message that is not only conveyed, but that is conveyed precisely, coherently, and appropriately" (Swain 1985, p. 249). A necessary way of improving comprehensible output is by speaking. Therefore, there is a necessity of communicative oriented foreign and second language classrooms that encourage and push students to produce the L2 (Allen, Fröhlich and Spada, 1983; Day, 1990; De la Fuente, 2002). Regarding this issue, De la Fuente (2002) found that "Some form of negotiation that incorporates pushed output may facilitate noticing" (p. 83). At the same time, there is also a metalinguistic function of output, which consists in making the students reflect on their L2 usage and eventually internalize new L2 forms (De la Fuente, 2002; Swain, 1990).

Output is especially important because it allows students to notice that in producing the target language "there is a gap between what they want to say and what they can say, leading them to recognize what they do not know, or know partially" (Swain 1995, p. 126). Noticing is a key element to fill their own gaps in knowledge in order for learners to acquire new vocabulary and linguistic forms. Nevertheless, in order for such noticing to take place a few conditions must be present-attention, awareness and consciousness (Gass, 1997). Schmidt (1990, 2011) in his noticing hypothesis stated that all noticing is conscious and the learner is conscious of noticing a gap in knowledge.

Another reason why the study of output is necessary is because with output it is possible to know if the student actually understands - "Learners (as well as native speakers, of course) can fake it, so to speak, in comprehension, but they cannot do so in the same way in production" (Swain 1995, p. 127). Creating awareness of what one's gaps in communication are, as well as using output to ensure student's understanding is very important characteristics of output. 
More recent literature on L2 output production also points to the necessity of creating ideal strategies for students to produce the L2. Weyers (2010) suggested the creation of courses addressing the development of speaking strategies at the three hundred level L2 conversation course.

\subsection{Beliefs on target language use}

In order to study beliefs it is necessary to know what we understand by beliefs, which sometimes is complicated to do because beliefs "...travel in disguise and often under an alias - attitudes, values, judgments, axioms, opinions ..." (Pajares 1992, p. 329), so that when people refer to one of the nouns mentioned here it may actually be that they are referring to beliefs. For our study we have adopted the definition proposed by Breen et al. (2001), teachers' beliefs are "personal theories that teachers hold regarding the nature of the broader educational process, the nature of language, how it is learned, and it may be best taught." (p. 472).

Beliefs may be hidden in the subconscious, because the individual is not aware of some of the beliefs he/she has. For that reason, "beliefs cannot be directly observed or measured but must be inferred from what people say, intend, and do ..." (Pajares 1992, p. 314). Therefore, in order to study them it is necessary not only to ask teachers what their beliefs are, but also to observe their classroom practice several times, so that the conscious and subconscious parts of their belief system could be captured.

Combining the topics of beliefs and second language teaching approaches among foreign and second language researchers Chaudron (1988) explained that:

...in the typical foreign language classroom, the common belief is that the fullest competence in the TL [target language] is achieved by means of the teacher providing a rich TL environment, in which not only instruction and drill are executed in the TL but also disciplinary and management operations (p. 121).

In Chaudron's opinion, the target language should be spoken as much as possible. He further states that the target language should not only related to instruction, but also to disciplinary words and commands for students to do in the classroom.

It is important to know what beliefs teachers hold in the issue of L1 and L2 alternation in the foreign language class in order to predict the teaching decisions they are likely to adopt. Besides, understanding the belief system of teachers and teacher candidates is essential to improving their professional preparation and teaching practices (Nespor, 1987; Pajares, 1992). This is especially important for student teachers, so that their future decisions could be influenced for them to avoid making the same mistakes their own teachers committed. As Pajares (1992) noted, "Evaluations of teaching and teachers that individuals make as children survive nearly intact into adulthood and become stable judgments that do not change, even as teacher candidates grow into competent professionals, able, in other contexts, to make more sophisticated and informed judgments" (p. 324). If changing beliefs is an unlikely situation, then prospective teachers, who still do not hold many beliefs regarding teaching practice, could be trained into alternative approaches to teaching, that if proven satisfactory could be adopted by the young teacher. This is an idea that is consistent with Guskey's (1986) findings that when teachers try a new procedure, which improves student achievement, teachers are likely to change their attitude. For this reason Guskey arrived at the conclusion that change in behavior happens first and then, after proven satisfactory, is followed by change of belief.

\section{NEED FOR THE STUDY AND RESEARCH QUESTIONS}

There are few previous studies done on the amount of L1 versus L2 discourse at the college level and how teachers' beliefs relate to practice. Among those few Duff and Polio (1990) analyzed the amount of target language versus English in 13 foreign language classrooms in a large university in California. This study was continued later (Polio and Duff, 1994), further analyzing 6 of the 13 classes of the previous study. Polio and Duff (1994) arrived at the conclusion that "the more comprehensible TL [target language] input (and output) available to the classroom learners, the better, and we believe that teachers can in fact be taught techniques for using more TL" (p. 323). Following on the steps of Polio and Duff, this research centers around the analysis of classroom speech, complimented by instructors' awareness of the language used in their classrooms. There are three research 
questions: What is the ratio of English and Spanish spoken in class? Is classroom speech more predominant in students or the instructor? And, are teachers' beliefs in regards to the use of English and Spanish consistent with their classroom practices?

\section{METHODOLOGY}

\subsection{Participants}

Participants were three college instructors and their students. There were two female instructors, teaching on a full time basis a section of a three hundred level Spanish conversation class at a small private college in the Northeast. The third instructor was a male part time instructor, teaching one section of the same class, at a state university, also in the Northeast. The three instructors were chosen due to their willingness and availability to participate in this study. The classes at both institutions took place on Mondays, Wednesdays and Fridays and lasted 50 minutes.

\subsection{Participant 1: Dr. Cervantes}

The first instructor, Dr. Cervantes (pseudonym) was born in Latin America. She came to the United States in the 1990's to pursue higher education and received a Ph.D. in Latin American literature. At the time of the research, Dr. Cervantes had five years experience teaching Spanish at the college level.

\subsection{Participant 2: Dr. Webster}

Dr. Webster (pseudonym) was originally from the United States, but resided several years in Spain. She pursued graduate studies in Spanish Literature at an Ivy League university and had over twenty years experience teaching Spanish at the college level.

\subsection{Participant 3: Mr. Castañeda}

Mr. Castañeda (pseudonym) was originally from South America. He received a bachelor's degree in Spanish education in his native country and continued with graduate studies in the United States in the late 1980's. $\mathrm{He}$ graduated with a master's degree in foreign language education and continued doctoral studies in foreign language education at a state university in the Midwest. A few years later, as an ABD, Mr. Castañeda returned to his home country. Due to his absence he was not able to finish writing his dissertation. Currently he teaches two classes at a state university in the Northeast.

\subsection{Procedure}

The semester previous to the study, the researcher met with each of the instructors and requested permission from the instructors and their institutions by means of an Institutional Review Board request. The week before conducting the recordings, the researcher met with each of the instructors for a 20-minute interview. After tape-recording and transcribing the interviews, the class visitations and tape recording of lessons started.

The research was conducted by tape-recording five classes of each instructor, for a total of fifteen 50minute lessons. All three sections of the same conversation course were covering the same chapter in a text called Conversación y Controversia.

\section{DATA COLLECTION}

The techniques for collecting the data were non-participant class observations, an interview with each instructor and the recording of classes. The class observations were performed by keeping a written record of the most relevant aspects that took place in the classroom, such as the students' responses to the teacher's input, the language used in the teacher's responses to the students, whether students or the instructor initiated the interaction, etc. 
The three instructors were interviewed previous to the beginning of the study and lasted approximately 20 minutes. The instructors focused into the instructors' life history emphasizing their educational background and work experience, their beliefs regarding the use of target language versus mother tongue and the instructor's perceived reactions from students towards the amount of target language used.

The lessons were recorded and then transcribed verbatim. The quantification of the amount of each language was estimated by using a 5-second sound device, adding the times that each language was used every 5 seconds and determining percentages for the use of each language.

\section{RESULTS}

\subsection{Results on quantification of amount of Spanish and English}

In general terms, the L2 was used more often than the L1 by the three instructors' classes. Table 1 shows the percentage of time spend by each instructor's class in each language.

Table 1: Percentages of the use of L1 and L2 in all three instructors

\begin{tabular}{|l|c|c|}
\hline \multicolumn{1}{|c|}{ Percentages } & English & Spanish \\
\hline Dr. Cervantes & $35.5 \%$ & $64.5 \%$ \\
Dr. Webster & $20.5 \%$ & $79.5 \%$ \\
Mr. Castañeda & $8.9 \%$ & $91.1 \%$ \\
\hline Mean & $\mathbf{2 1 . 6 3 \%}$ & $\mathbf{7 8 . 3 7 \%}$ \\
\hline
\end{tabular}

In Table 1 we see that although percentages varied from one class to another, on an average $21.63 \%$ of class time was spent speaking English. On the other hand, the target language was used more often during class than the mother tongue $(78.37 \%)$.

In Dr. Cervantes' class, there was an average of $35.5 \%$ of use of English, the highest rate from all three instructors. Spanish was spoken $64.5 \%$ of the time, as we see in Table 1. In comparison to the other two sections, Dr. Cervantes and her students used the L1 more often than her colleague Dr. Webster and far more than Mr. Castañeda. In Dr. Cervantes' class more than one third of the lesson took place in English.

Dr. Webster, on the other hand, used an average of $20.5 \%$ of English in class and $79.5 \%$ of Spanish in class, which amounts to almost four times as much target language spoken during the 5 lessons recorded.

Mr. Castañeda was the instructor who spoke the target language more often. $91.1 \%$ of the time Spanish was spoken, as opposed to only $8.9 \%$ use of English, an ideal situation according to researchers in the field. While percentages of time spent speaking each language is important and necessary to know, a further analysis of the type of speech is also important.

\subsection{Results on distribution of speech}

As we saw in the previous section, in Dr. Cervantes' classes English was spoken an average of $35.5 \%$ of the time, but when analyzing the teacher to student ratio, we see in table 2 that Dr. Cervantes spoke more often than her students, as her speech took place $54.8 \%$ of the time, while the students occupied $45.2 \%$ of the time lesson.

Table 2: Average of Dr. Cervantes' Classes

\begin{tabular}{|c|c|c|c|c|c|}
\hline \multicolumn{3}{|c|}{ L1 - English } & \multicolumn{2}{|r|}{ L2 - Spanish } & \multirow{3}{*}{$\begin{array}{c}\text { Total by Category } \\
54.8 \%\end{array}$} \\
\hline Teacher Initiates & $16 \%$ & \multirow{2}{*}{ Total L1 Teacher $19 \%$} & $33 \%$ & \multirow{2}{*}{ Total L2 Teacher $35.8 \%$} & \\
\hline Teacher Responds & $3 \%$ & & $2.8 \%$ & & \\
\hline Student Initiates & $11.1 \%$ & \multirow{2}{*}{ Total L1 Student $16.5 \%$} & $12.3 \%$ & \multirow{2}{*}{ Total L2 Student $28.7 \%$} & \multirow{2}{*}{$45.2 \%$} \\
\hline Student Responds & $5.4 \%$ & & $16.4 \%$ & & \\
\hline Total & $35.5 \%$ & & $64.5 \%$ & & $100 \%$ \\
\hline
\end{tabular}


Based on Table 2, we see that in Dr. Cervantes' classes, out of the $54.8 \%$ of teacher speech, $19 \%$ was in English, a large percentage taking into account that this was a three hundred level Spanish conversation course. Out of the student speech, we see that most of the time students spoke in Spanish (28.7\%), more often answering questions or engaging in conversation.

In Dr. Websters' classes the percentage of target language spoken in class (79.5\%) was higher than in that of her colleague, Dr. Cervantes (64.5\%). In the Table 3 we observe more information on Dr. Websters' classes distribution of speech.

Table 3: Average of Dr. Webster's classes

\begin{tabular}{|c|c|c|c|c|c|}
\hline \multicolumn{3}{|c|}{ L1 - ENGLISH } & \multicolumn{2}{|r|}{ L2 - SPANISH } & Total by Category \\
\hline Teacher Initiates & $2.1 \%$ & \multirow{2}{*}{ Total L1 Teacher $6.9 \%$} & $16.6 \%$ & \multirow{2}{*}{ Total L2 Teacher 29.4} & \multirow{2}{*}{$36.3 \%$} \\
\hline Teacher Responds & $4.8 \%$ & & $12.8 \%$ & & \\
\hline Student Initiates & $6.3 \%$ & \multirow{2}{*}{ Total L1 Student $13.6 \%$} & 18.7 & \multirow{2}{*}{ Total L2 Student $50.1 \%$} & \multirow{2}{*}{$63.7 \%$} \\
\hline Student Responds & $7.3 \%$ & & $31.4 \%$ & & \\
\hline Total & $20.5 \%$ & & $79.5 \%$ & & $100 \%$ \\
\hline
\end{tabular}

Table 3 demonstrates that in Dr. Websters' classes there was also a higher rate of student speech $(63.7 \%)$, as opposed to $45.2 \%$ in Dr. Cervantes' classes. Another important issue to notice is the fact that $50.1 \%$ of the total class time students were speaking in Spanish, while the rest of the time either the instructor was speaking or students were using their primary language, which took place $13.6 \%$ of the time.

The situation in Mr. Castañedas' classes at the state university was quite different from the speech used at the private college. In Table 4 we see information regarding Mr. Castañedas' classes.

Table 4: Average of Mr. Castañeda's classes

\begin{tabular}{|c|c|c|c|c|c|}
\hline \multicolumn{3}{|c|}{ L1 - ENGLISH } & \multicolumn{2}{|r|}{ L2 - SPANISH } & \multirow{3}{*}{$\begin{array}{c}\text { Total by Category } \\
59.3 \%\end{array}$} \\
\hline Teacher Initiates & $1.1 \%$ & \multirow{2}{*}{ Total L1 Teacher $2.7 \%$} & $31.5 \%$ & \multirow{2}{*}{ Total L2 Teacher $56.6 \%$} & \\
\hline Teacher Responds & $1.6 \%$ & & $25.1 \%$ & & \\
\hline Student Initiates & $4.1 \%$ & \multirow{2}{*}{ Total L1 Student $6.2 \%$} & $13.9 \%$ & \multirow{2}{*}{ Total L2 Student 34.5} & \multirow{2}{*}{$40.7 \%$} \\
\hline Student Responds & $2.1 \%$ & & $20.6 \%$ & & \\
\hline Total & $8.9 \%$ & & $91.1 \%$ & & $100 \%$ \\
\hline
\end{tabular}

Mr. Castañedas' classes saw the highest amount of Spanish speech from all three instructors, given that 91.1\% of the time Spanish was spoken. Nevertheless, his classes also had a high rate of teacher talk, 59.3\%, as opposed to $40.7 \%$ of student speech. This finding resembles the ratio taken place in Dr. Cervantes' classes, in which teacher talk amounted to $54.8 \%$ while student speech took place the reminding $45.2 \%$ of the time.

\subsection{Results on teachers' beliefs in relationship to actual practice}

Dr. Cervantes believes that "At this level teaching should be mostly in Spanish, but if students don't understand an important issue, then one can use English to clarify what was not clear." Regarding the amount of L1 and L2 she believes she uses in class, she said: "Whenever possible I speak Spanish to teach grammar concepts, to practice and review them, once in a while, when it is a difficult point or when a test is coming up, like last week, I have to speak English to make sure that the students understand, because that's why I am in the classroom, to clarify things and to make sure they understand. But when it is a normal day I use Spanish almost all the time"

In Dr. Cervantes' classes there was a high percentage of use of English, which seems to indicate lack of awareness of the high percentage of L1 spoken in class.

These results also reflect an inconsistency with Dr. Cervantes' beliefs on the language used for grammar instruction. She indicated during the interview: "I think the best way to teach a language is by using it. I try to use Spanish in class almost all the time." In the case of this class, as represented in Table 2, there was almost twice the use of English as Spanish on the part of the instructor. 
In regards to Dr. Webster's beliefs regarding the use of L1 and L2 she expressed: "The percentage that I would like to use and the percentage that I use are two different things. I would say that I would like to use, say ninety percent Spanish and ten percent English. I think I end up doing more like maybe, maybe sixty-forty is what it ends up been, but every once in a while, as I said, I have a good day and the percentage goes, goes way up. Depends really on how I react to the way they react that day".

Dr. Websters' classes had a close to $20 \%-80 \% 11$ to $\mathrm{L} 2$ ratio, which resembles her opinion of ideally having a 10\%-90\% L1 to L2 ratio, but probably incurring into a higher rate of L1. On another issue, a very positive feature observed was the fact that Dr. Websters' students engaged in the highest rate of student speech from all three classes, $63.7 \%$ of class time, meaning that almost two thirds of the time a student was speaking in her class.

At the same time, Mr. Castañeda expressed that he uses Spanish almost all the time in class.

I would say that normally it's close to one hundred percent Spanish. I only use English once in a while to make sure that everyone has understood. For instance, when I am giving instructions about announcements or certain things I want to make sure, so I say that in Spanish and then I say, Ok. I want to make sure that we all understand and then what I have said is this. But of course, in all that is going on in the class, the discussions that we have, everything, is in Spanish.

Taking into account that Mr. Castañeda considered his classes to be almost 100\% in Spanish, the actual average amount of L2 for his five classes was $91.1 \%$, while the L1 was spoken $8.9 \%$ of the time. These results seem to indicate that Mr. Castañeda is aware of the amount of L1 and L2 that take place in his classroom. The very high amount of target language use meets the requirement of continuous use of target language as an assumption of good foreign language teaching practice (Chaudron, 1988; Day, 1985; Ellis, 1984; Krashen, 1985). language:

Regarding Mr. Castañeda's teaching practice and the value he assigns to communication in the target

... at all times I emphasize that [communication] and also, as the students speak and I realize that there is a problem immediately I take that opportunity to try to teach a little bit of grammar or whatever or remind them of any particular point of grammar that they are not using properly. And that seems to me that it works well, because when you learn things in those circumstances that are not kind of formal, but that's what you find and you move along and work with the language that's very good.

In practice, in Mr. Castañedas' classes there was much emphasis on grammar and error correction, but communication, in the sense of conversation, is only expected during the first few minutes of class. After these initial moments the class centered on grammar, with the students having the option of choosing the topic, since they are expected to use a specific tense, but the choice of vocabulary relied on the students. In this sense, there seems to be a disparity between his beliefs on the emphasis he puts on communication and the actual practice, that centers on grammar.

\section{DISCUSSION}

Through calculating the amount of English and Spanish use in class, we see that results vary, with Mr. Castañedas' classes showing a predominant L2 speech presence in the classroom. Nevertheless, this single aspect of language does not guarantee that other important features in the learning of a foreign language are met. In that sense, negotiation of meaning is a very important missing characteristic in the three instructors' classes observed. In the case of Dr. Cervantes, when explaining grammatical notions, she frequently resorted to speaking in English.

Using the L1 denied students a valuable opportunity to "work together linguistically to repair or resolve impasses in communication ..." (Pica 1996, p.2). At the same time, L1 speech as the one exemplified here takes away the possibility of providing students with comprehensible input and, at the same time, of students producing comprehensible output. As a matter of fact, there were no instances of negotiation of meaning in Dr. Cervantes' classes, while there were very few in Dr. Websters' and Mr. Castañedas' classes. 
A further analysis of the language also shows that L2 output was not encouraged enough in Dr. Cervantes and Mr. Castañedas' classes, as identified in tables 2 and 4. This situation took place especially in Dr. Cervantes' classes, in which the average student L2 output covered $28.7 \%$ of the total class time, as opposed to $34.5 \%$ in Dr. Websters' classes and $50.1 \%$ in Mr. Castañeda's course. At the same time, class observation and recording of classes showed two important issues: Predominance of teacher-student one-on-one interaction and also emphasis on grammatically related speech. Regarding the predominance of teacher-student one-on-one interaction, it was noticed that there were very few instances in all three classrooms of either pair or group work activities, which allow more instances for student to produce L2 output. The second issue, the predominance of grammatically oriented speech was very common in Dr. Cervantes and Mr. Castañedas' classes.

In regards to the ratio student to teacher speech, we also see a variety of results, ranging from more student to teacher talk from the part of Dr. Webster to a preponderance in teacher speech, as in the case of Mr. Castañedas' classes. This finding seems to indicate that two out of the three classes observed were teacher-centered classrooms, a practice that is not conducive to fostering student output. This finding is not uncommon, Holmes (1978) found that research from all over the world demonstrates a similar pattern of high rate of teacher speech. Also, years later Allwright and Bailey (1991) indicated that "Observations of many different classes, both in content area subjects and in language instruction, consistently show that teachers typically do between one half and three quarters of the talking done in classrooms" (p. 139). Two decades later, teacher centered classrooms continue to take place.

Regarding the way teacher beliefs transpire into their practice, it was found that in two of the instructors the amount of L1 and L2 matched their belief system. Dr. Cervantes expressed that she believes that using the L2 as much as possible is in the students' best interest, a belief not met in the practice. Dr. Webster explained that she would like to use more Spanish in the classroom than the amount she ends up using, which shows her awareness of language use. At the same time, Mr. Castañeda had stated that in rare occasions he allows the L1 in class, which was found to be accurate.

\section{CONCLUSION}

Two out of the three Spanish classes observed in this study showed an increasing amount of teacher rather than student speech. It was also observed that there was a predominant focus on grammatical forms. Having a focus on linguistic forms and, at the same time, teacher centered classrooms, is a combination that allows little possibility of interaction in the target language. This focus on language form and not in communication creates a restriction on the amount and linguistic forms of language produced by the students.

Based on the findings in this study it is recommended that foreign language instructors be trained in alternative approaches that allow more communication in the target language. It would also be of great benefit for future foreign language teachers to be video- taped or tape recorded in order for them to be aware of the speech characteristics of their lessons. A second recommendation consists on rehearsing activities and learn alternative approaches. As Antón (1999) suggested: "Teachers can engage learners in the negotiation of meaning, language forms, and classroom rules by using various discoursive moves, and in so doing can also promote learner's active mental participation, which may have a role in L2 learning" (p. 305).

It is also recommended that future language instructors participate in pedagogical training. If trained in communicatively oriented methods, future teachers may adopt such approaches for language teaching.

Given that input, output and negotiation of meaning are important issues for teaching a foreign language, the activities that take place in the classroom should be conducive to these three aspects of language learning. For this reason, communicatively oriented classes are necessary. Activities that are conducive to communicatively oriented classrooms, such as pair and group work, dictogloss, conversation, and debates, force students to understand, negotiate and produce language with the help of peers, which provides a less intimidating and more helpful way for students to interact with their classmates and ask for clarification.

It is important that beliefs are challenged from the beginning of the professional career because the earlier a belief is incorporated into the belief structure, the more difficult it is to change (Pajares, 1992; Nespor, 1987; Nisbett \& Ross, 1980). 
This research study provides a generic view on target language versus primary language use in college level foreign language classrooms. The researcher concurs with Polio and Duff (1994) that "conscious raising among teachers is important because they may not realize the extent to which they use English" (p. 323). The researcher also agrees with Weyers (2010) on the necessity of conversation courses that address speaking strategies for advanced L2 learners. It is the author's hope that more research in this area will follow.

\section{AUTHOR INFORMATION}

Graziela Rondon-Pari, Ph.D. Assistant Professor of Spanish at SUNY Brockport. Received Ph.D. in Second and Foreign Language Education from the University at Buffalo in 2006. She specializes in foreign language proficiency and is a certified Oral Proficiency Rater with the American Council of the Teaching of Foreign Languages (ACTFL). E-mail: grondonp@brockport.edu

\section{REFERENCES}

1. Allen, P., Fröhlich, M., \& Spada, N. (1984). The communicative orientation of language teaching: An observation scheme. In J. Handscombe, R. A. Oream, \& B. P. Taylor (Eds.), On Tesol '83 (pp. 231-252). Bloomington, Illinois: Pantagraph Printing.

2. Allbright, D., \& Bailey, K. (1991). Focus on the Language Classroom. Cambridge, UK: Cambridge University Press.

3. Anton, M. (1999). The discourse of learner-centered classroom: Sociocultural perspectives on teacherlearner interaction in the second language classroom. The Modern Language Journal, 83(3), 303-318.

4. $\quad$ Breen, M. P., Hird, B., Milton, M., Oliver, R. \& Thwaite, A. (2001). Making sense of language teaching: Teachers' principles and classroom practices. Applied Linguistics 22(4), 470-501.

5. Chaudron, C. (1988). Second Language Classrooms. Research on Teaching and Learning. New York: Press Syndicate of the University of Cambridge.

6. Day, R. (1985). The use of the target language in context and second language proficiency. In S. Gass, \& C. Madden (Eds.), Input in Second Language Acquisition (pp. 257-271). Rowley, MA: Newbury House.

7. Day, R. (1990). Teacher observation in second language teacher education. In J. Richards and D. Nunan, (Eds). Second Language Teacher Education (pp. 43-61). Cambridge, UK: Cambridge University Press.

8. De la Fuente, M. J. (2002). Negotiation and oral acquisition of L2 vocabulary: The roles of input and output in the receptive and productive acquisition of words. Studies in Second Language Acquisition, 24, 81-112.

9. Duff, P., \& Polio, C. (1990). How much foreign language is there in the foreign language classroom? The Modern language Journal, 74, 154-166.

10. Ellis, R. (1984). Classroom Second Language Development. Oxford: Pergamon.

11. Gass, S. (1997). Input, Interaction and the Second Language Learner. Mahwah, NJ: Erlbaum.

12. Guskey, T. R. (1986). Staff development and the process of teacher change. Educational Researcher, 15(5), 5-12.

13. Holmes, J. (1978). "Sociolinguistic competence in the classroom." In J. Richards (Ed.), Understanding Second and Foreign Language Learning (pp. 134-163). Rowley, MA. Newbury House.

14. Krashen, S. (1985). The Input Hypothesis: Issues and Implications. London: Longman.

15. Long, M. (1996). The role of the linguistic environment in second language acquisition. In W. C. Ritchie \& T. J. Bhatia (Eds.), Handbook of Second Language Acquisition (pp. 413-468). New York: Academic Press.

16. Mackey, A. \& Abbuhl, R. (2006). Input and interaction. In C. Sanz (Ed.). Mind and Context in Adult Second Language Acquisition (pp. 207-233). Washington, DC: Georgetown University Press.

17. Nespor, J. (1987). The role of beliefs in the practice of teaching. Journal of Curriculum Studies, 19(4), 317328.

18. Nisbett, R., \& Ross, L. (1980). Human Inference: Strategies and Shortcomings of Social Judgment. Englewood Cliffs, NJ: Prentice-Hall, Inc.

19. Pajares, F. (1992). Teachers' beliefs and educational research: Cleaning up a messy construct. Review of Educational Research, 62(3), 307-332.

20. Pica, T. (1987). Interlanguage adjustments as outcome of NS-NNS negotiated interaction. Language Learning, 38(1), 45-73. 
21. Pica, T. (1996). Do second language learners need negotiation? International Review of Applied Linguistics, 34, 1-21.

22. Polio, C., \& Duff, P. (1994). Teachers' language use in university foreign language classrooms: A qualitative analysis of English and target language alternation. The Modern Language Journal, 78, 313326.

23. Sanz, C., \& Morgan-Short, K. (2006). Explicitness in pedagogical interventions: Input, practice, and feedback. In C. Sanz (Ed.). Mind and Context in Adult Second Language Acquisition (pp. 234-263). Washington, DC: Georgetown University Press.

24. Savignon, S. (1972). Communicative Competence: An Experiment in Foreign Language Teaching. Philadelphia : Center for Curriculum Development.

25. Savignon, S. (1991). Communicative language teaching: State of the art. TESOL Quarterly, 25(2), 261-277.

26. Schmidt, R. (1990). The role of consciousness in second language learners. Applied Linguistics 11(1), 1746.

27. Schmidt, R. (1995). Consciousness and foreign language learning: A titorial on the role of attention and awareness in learning. In R. Schmidt (Ed.), Attention and Awareness in Foreign Language Learning (pp. 163). Honolulu: University of Hawaii Press.

28. Schmidt, R. (2001). Attention. In P. Robinson (Ed.), Cognition and Second Language Instruction (pp. 332). Cambridge, UK: Cambridge University Press.

29. Seidman, I. (1998). Interviewing as Qualitative Research. New York: Teachers College Press.

30. Selinker, L. (1972). Interlanguage. International Review of Applied Linguistics, 10, 209-231.

31. Swain, M. (1985). Communicative competence: Some roles of comprehensible input and comprehensible output in its development. In S. M. Gass \& C. Madden (Eds.), Input in Second Language Acquisition (pp. 235-253). Rowley, MA: Newbury House.

32. Swain, M. (1995). Three functions of output in second language learning. In G. Cook \& B. Seidhofer (Eds.), Principle and Practice in applied linguistics; studies in honour of H. G.Widdowson (pp. 125-144). Oxford: Oxford University Press.

33. Weyers, J. (2010). Speaking Strategies: Meeting NCATE oral proficiency standards. Foreign Language Annals 43(3), 384-394. 